\title{
Non-Hodgkin's Lymphoma as a Mimicker in Osteomyelitis: A Case Report
}

\author{
Soheil Ebrahimpour ${ }^{1}$, Zeinab Mohseni Afshar'2, Zeinab Sheidaie3, \\ Mahmoud Sadeghi-Haddad-Zavareh ${ }^{1}$, Arefeh Babazadeh ${ }^{1}$ \\ ${ }^{1}$ Infectious Diseases and Tropical Medicine Research Center, Health Research Institute, \\ Babol University of Medical Sciences, Babol, I.R. Iran \\ ${ }^{2}$ Department of Infectious Diseases, Kermanshah University of Medical Sciences, Kermanshah, I.R. Iran \\ ${ }^{3}$ Department of Internal Medicine, School of Medicine, Babol University of Medical Sciences, Babol, I.R. Iran
}

\section{SUMMARY}

Non-Hodgkin's lymphoma (NHL) patients who have bone involvement are rarely seen. These patients exhibit very different clinical manifestations in comparison with the normal cases of these types of cancers.

We report a case of NHL, firstly treated as osteomyelitis case of unidentified etiology. This case showed the difficulties that may occur while diagnosing this issue.

The histopathological diagnosis is the final confirmation of this disease. Moreover, the primary and essential treatment for these patients is chemotherapy.

Key words: Non-Hodgkin's lymphoma, osteomyelitis, immunohistochemistry

Corresponding author:

Arefeh Babazadeh

Email: drbabazadeh.a@yahoo.com 


\section{INTRODUCTION}

Vertebral osteomyelitis is one of the important diagnoses that should always be considered in the patients with recent onset of low back pain or neurological disorders related to the root of the spinal nerve, along with fever or increase in other inflammatory markers or a positive blood culture (1). This is because patients with low back pain are often treated with conservative and even surgical treatments for discopathy, while in some cases the symptoms of the patient are the result of infectious agents or vertebral osteomyelitis $(2,3)$. In these patients, backgrounds such as peripheral vascular catheters, diabetes mellitus, and other predisposing conditions should be considered and lead us to this diagnosis. Additionally, tuberculosis (TB) and brucellosis should be considered in endemic areas $(4,5)$. In the examination of vertebral lesions, rarer cases such as primary or metastatic malignancies should also be considered in addition to infectious agents. In some cases, lymphoma in particular, despite the low incidence of bone involvement due to the presence of B symptoms and increased inflammatory markers, they are subject to the diagnostic ambiguity of vertebral osteomyelitis (6). Sometimes, they are difficult to differentiate in imaging, and ultimately what helps us reach the final diagnosis is the histopathological examination of the lesion of the vertebral body. The current study presents the patient with initial signs of vertebral osteomyelitis. After the biopsy of vertebral lesions, IHD was diagnosed and B-cell non-Hodgkin's lymphoma was confirmed.

\section{CASE REPORT}

The patient was a 35-year-old woman who reported having the low back pain over the past five months (two months after childbirth). Her pain was sharp, intermittent, and without distribution, but became persistent gradually. The pain increased with activity and decreased with rest. At first, she responded to sedatives, but gradually a progressive course was developed and even awakened the patient at night. Her pain intensified two weeks before the visit and distributed to the pelvic region and femur. The patient reported five kilograms of weight loss over the past five months. She also reported fever, night sweats, and paresthesia. The history of trauma, fracture or certain disease was not mentioned. She had a history of cesarean section seven months before.

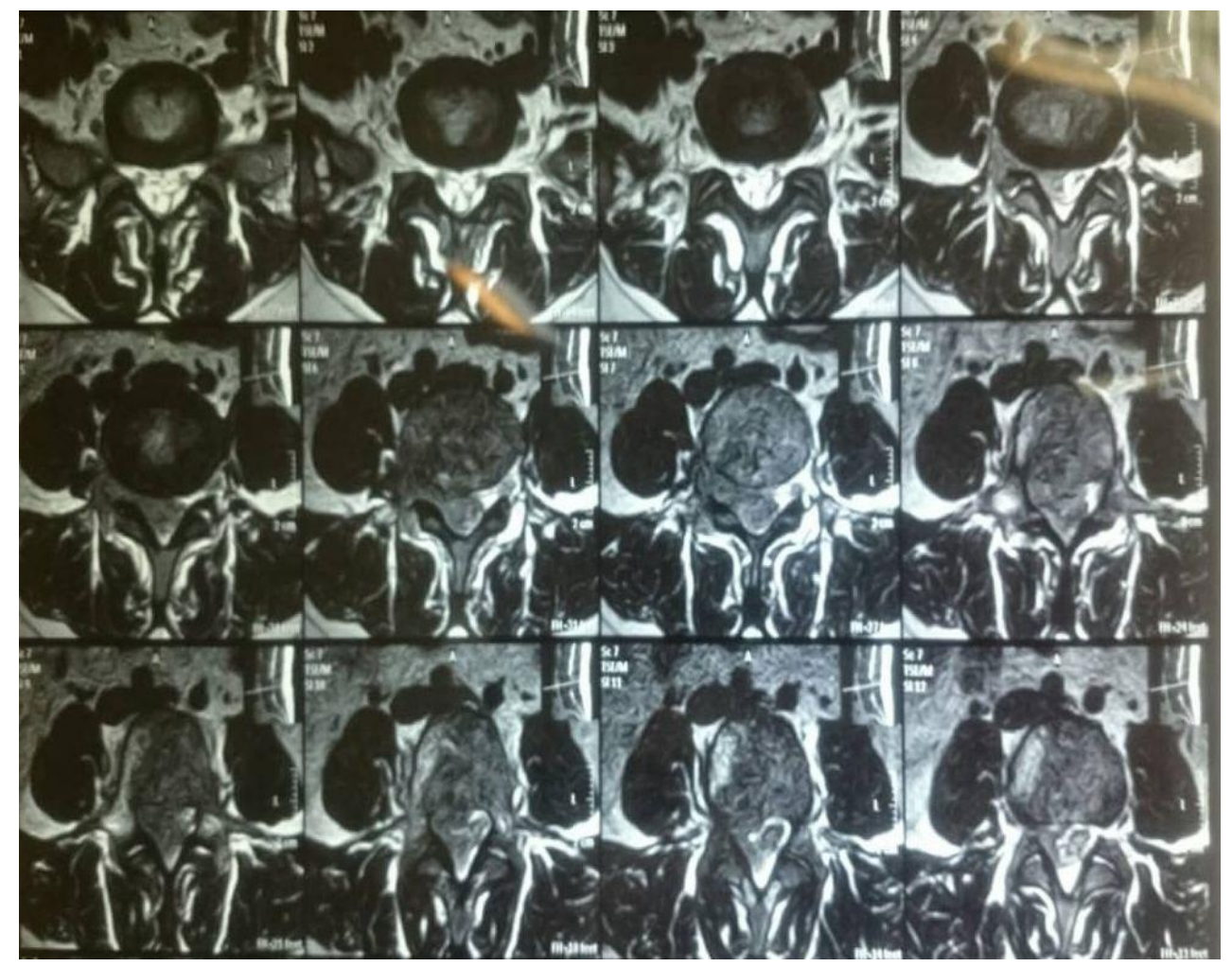

Figure 1. Magnetic resonance imaging( MRI) of spine showed disk bulging in L3/L4 level, low signal lesion in T1, Iso signal in T2 and at L3-L4, L5 vertebral bodies with extension to thecal sac at 14 
Regarding the history of medications, she mentioned the use of different types of nonsteroidal anti-inflammatory drugs (NSAIDs) and vitamin D supplements. She was ill in appearance, and when standing, tended to bend forward.

Cesarean scar was seen on the abdomen in the examination. The examination of the cranial nerves was normal. In the right lower extremity examination, decreased muscle tone, muscle strength of $2 / 5$, weakness in the extensor region of the knee and lower leg, sensory loss in the anteromedial thigh, decreased patellar ref-lexes and positive Slr (Straight Leg Raise) were observed. The patient was referred to a neurosurgeon, and with a possibility of sciatic involvement, she was recommended to rest and undergo a series of tests. The patient visited the doctor two weeks later, and since the pain did not decreased, magnetic resonance imaging (MRI) of the spine without contrast was requested, and physiotherapy was recommended. The results of the required laboratory tests in the first step were as follows: white blood cell (WBC) $11300 / \mu \mathrm{L}$ (PMN:72\%), erythrocyte sedimentation rate (ESR): $86 \mathrm{~mm} / \mathrm{hr}$, C-reactive protein (CRP): 54 $\mathrm{mg} / \mathrm{dL}$, aspartate aminotransferase (AST): $13 \mathrm{U} / \mathrm{L}$, alanine aminotransferase (ALT):19 U/L, alkaline phosphatase (ALP): $211 \mathrm{U} / \mathrm{L}$, rheumatoid factor (RF):9 IU/mL, hemoglobin (Hgb): $12.5 \mathrm{~g} / \mathrm{dL}$, platelets (PLT): 285000 $\mathrm{U} / \mathrm{L}$, lactate dehydrogenase (LDH): $574 \mathrm{U} / \mathrm{L}$, Vit D: 41 $\mathrm{ng} / \mathrm{mL}$, moreover, antinuclear antibodies (ANA), human immunodeficiency virus (HIV) test, hepatitis B virus surface antigen (HBsAg), and hepatitis $\mathrm{C}$ virus (HCV) test were negative.

The finding of spine MRI was as follows: disk bulging in L3/L4 level was seen. Low signal lesion in T1, Iso signal in T2. At L3-L4, L5 vertebral bodies with extension to thecal sac at 14 level were noted (Figure 1). Subsequently, the results of laboratory tests were requested: purified protein derivative (PPD) was negateve, urine protein electrophoresis (UPEP): NL, a-fetoprotein (aFP) $2.8 \mathrm{ug} / \mathrm{L}$, carcinoembryonic antigen (CEA): 0/8 ng/mL, CA125: $13.73 \mathrm{U} / \mathrm{mL}$, cancer antigen 15-5 (CA 15$5)=5.2 \mathrm{U} / \mathrm{mL}$, cancer antigen 19-9 (CA 19-9): $9.48 \mathrm{U} / \mathrm{mL}$, wright test, and 2-mercaptoethanol (2-ME) test were normal.

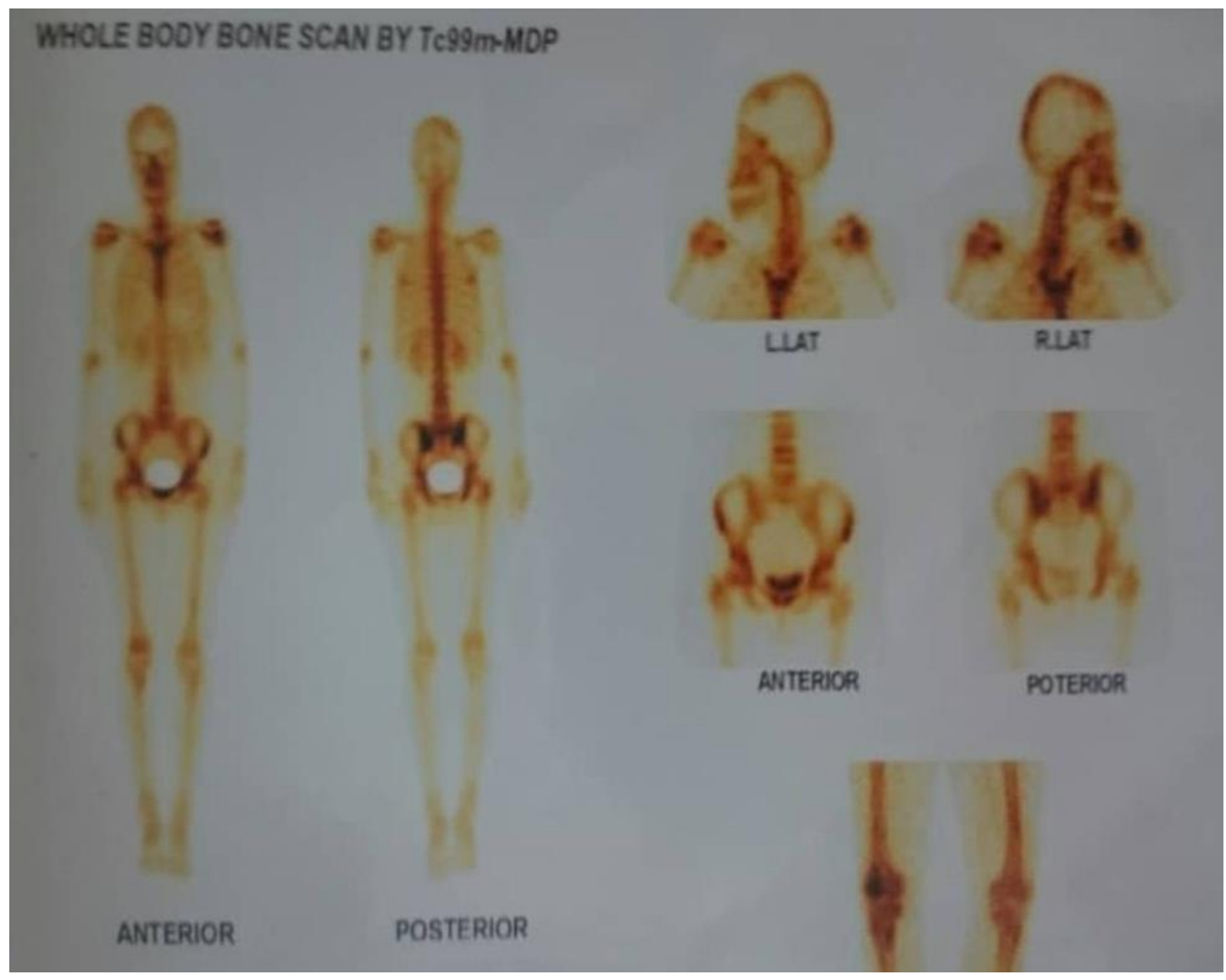

Figure 2. Bone scan showing osteomyelitis and malignancies 
In the bone scan, the pattern of increased absorption in the affected areas indicated osteomyelitis and malignancy as the main diagnoses (Figure 2). According to the findings of MRI and bone scan, a vertebral sampling was performed, and based on the examination of culture and pathology results, myelofibrosis along with necrosis, mononucleosis spots, and degenerated cells were reported, which was consistent with B-cell non-Hodgkin's lymphoma.

Immunohistochemistry (IHC) staining results were reported as follows:

$$
\mathrm{CD} 20^{+}, \mathrm{LCA}^{+}, \mathrm{CD}^{+} 0^{+}, \mathrm{CD}^{+} 5^{+}, \mathrm{PAX}^{+}, \mathrm{K}^{2} 7^{+}
$$

Besides spiral computerized tomography (CT) scans of the lungs, abdomen, and pelvis, mammography and ultrasound of the breast and bilateral axillary were performed, all of which were normal. Therefore, diagnosis of B-cell primary bone lymphoma without metastasis was reported to the patient, and she was referred to oncologist for chemotherapy. In the subsequent follow up, it was found that the patient was alive.

\section{DISCUSSION}

In this patient, neurological symptoms could be justified by finding the primary lesion in the vertebral body. However, based on the primary factor of the vertebral lesions in this patient, and considering leukocytosis, increase in inflammatory markers, fever and sweating, pyogenic osteomyelitis, brucellosis, and TB were important differential diagnoses. The result of serum tube agglutination test (SAT) for brucellosis was negative, probably because the patient was still at an early stage of brucellosis. On the other hand, induration was not observed in the tuberculin skin test (TST) that was performed with the patient. In cases of bone involvement, we expect it to be reactive in most cases, and this probability became less pronounced, although none of them rejected the diagnosis, and considering the patient's residence in the endemic area, these probabilities should be kept in mind and the histopathological examination of the lesion should be done in terms of these factors. On the other hand, several blood cultures were examined for this patient, none of which indicated the presence of bacteremia and subsequent pyogenic vertebral osteomyelitis (PVO).

The extension of the lesion of the intervertebral disc and the multi-level involvement of vertebrae reduced the likelihood of bone metastases and brought tuberculosis and bone lymphomas into consideration. It sho- uld be noted that compared to brucellosis, which tends to interfere with lumbar vertebrae, tuberculosis tends to interfere with thoracic vertebrae, and is less likely to destroy vertebral bodies and create the deformity (7-9).

Due to the lack of findings in favor of the infectious origin of this vertebral lesion, the patient underwent biopsy, and a neurosurgeon performed the biopsy on the T1 vertebral lesion. In the histopathologic study, necrosis and mononuclear cell infiltration were observed, and B-Cell Non-Hodgkin Lymphoma was confirmed in the patient through IHC staining. Considering the normal PBS of the patient and the lack of plasmablastic lymphoma (PBL), peripheral or mediastinal lymphadenopathy and primary bone marrow lymphoma were suspected. PBL causes primary bone marrow involvement in less than $1 \%$ of cases, and most cases of bone involvement are bone marrow involvement in the pathway of systemic lymphoma (10). The mean age of involvement in the PBL is about the age of sixty $(11,12)$. Therefore, the young age of our patient challenges this diagnosis. Also, the most common manifestation of PBL localizes bone pain in the vertebra, and we expected less neurological symptoms (13). Increase in inflammatory markers, such as erythrocyte sedimentation rate (ESR) and constitutional symptoms, is the common finding in osteomyelitis and lymphoma. The leukocytosis observed in this patient, who has polymorphonuclear predominance can be due to arbitrary use of cortico-steroid drugs by patients. It is noteworthy that because the histopathology of the PBL is polymorphic, it can mimic chronic osteomyelitis. Therefore, it is essential that IHC staining is performed at a time when the patient's lymphoma conditions are listed as important differential diagnosis so that this important diagnosis is not neglected for the histopathology that matches chronic osteomyelitis.

\section{CONCLUSION}

The case presented in this report elucidates the possibility of osteomyelitis or vertebral malignancies that should always be considered along with discopathy in low back pain or a sudden onset of neurological symptoms, and given that these two categories often overlap in laboratory findings and radiography, especially in the absence of microbiological or serological evidence of infection, biopsy should be considered for proper diagnosis. Even if the histopathologic diagnosis is in favor of chronic osteomyelitis, but no proper treatment response is achieved, the biopsy should be repeated (preferably by surgical biopsy), and IHC staining should be done for malignancy. 


\section{Acknowledgements}

Authors thank the Department of Internal Medicine of Babol University of Medical sciences, Iran and
Marzieh Nourollahzadeh for English editing the manuscript.

\section{Conflicts of interests}

There are no conflicts of interest 


\section{References}

1. Lopez-Rivera F, Rivera XC, Monroig HG. Vertebral Osteomyelitis: Unexpected Cause of Back Pain. J Med Cases 2017;8:246-8 https://doi.org/10.14740/jmc2870w

2. Zimmerli W. Vertebral Osteomyelitis. N Engl J Med 2010;362:1022-9. https://doi.org/10.1056/NEIMcp0910753

3. Mitsutake A, Matsumoto H, Hatano K, et al. Pneumococcal meningitis with vertebral osteomyelitis, iliopsoas abscess, and infected abdominal aortic aneurysm. Neurol Clin Neurosci 2018;6:23-5 https://doi.org/10.1111/ncn3.12175

4. Garg RK, Somvanshi DS. Spinal tuberculosis: A review. J Spinal Cord Med 2011;34:440-54. https://doi.org/10.1179/2045772311Y.0000000023

5. Horasan ES, Colak M, Ersoz G, et al. Clinical findings of vertebral osteomyelitis: Brucella spp. versus other etiologic agents. Rheumatol Int 2012;32:344953.

https://doi.org/10.1007/s00296-011-2213-3

6. Majeed A, Chan O, Okolo O, et al. Hodgkin Lymphoma Mimicking Osteomyelitis. Case Rep Oncol 2017;10:542-7

https://doi.org/10.1159/000474938

7. Rasouli MR, Mirkoohi M, Vaccaro AR, et al. Spinal Tuberculosis: Diagnosis and Management. Asian Spine J 2012;6:294-308.

https://doi.org/10.4184/asj.2012.6.4.294
8. Jain AK, Kumar J. Tuberculosis of spine: neurological deficit. Eur Spine J 2013;22:624-33.

https://doi.org/10.1007/s00586-012-2335-7

9. Yang B, Hu H, Chen J, et al. The Evaluation of the Clinical, Laboratory, and Radiological Findings of 16 Cases of Brucellar Spondylitis. Biomed Res Int 2016; 2016. 8903635.

https://doi.org/10.1155/2016/8903635

10. Harmon CM, Smith LB. Plasmablastic lymphoma: a review of clinicopathologic features and differential diagnosis. Arch Pathol Lab Med 2016;140:1074-8 https://doi.org/10.5858/arpa.2016-0232-RA

11. Yamada T, Kitamura N, Sasabe E, Yamamoto T. Plasmablastic lymphoma of the upper gingiva in an HIV-negative elderly patient. Oral Maxillofac Surg Cases 2015;1:19-24.

https://doi.org/10.1016/j.omsc.2015.05.002

12. Zhang $H$, Jia $X$, Wang $Y$, et al. Plasmablastic lymphomaof the ileum with longer survival time: A rare case report and review. Int J Clin Exp Pathol 2017; 10:4866-73.

13. Lei $\mathrm{Y}, \mathrm{Zi} \mathrm{L}$, Long $\mathrm{S}$, et al. Primary Bone Lymphoplasmacytic Lymphoma Presenting with Spinal Cord Compression: A Case Report. Turk J Haematol 2013;30:409-12.

https://doi.org/10.4274/Tjh.2012.0072 


\title{
Nehočkinova limfom kao imitator kod osteomijelitisa: prikaz slučaja
}

\author{
Soheil Ebrahimpour ${ }^{1}$, Zeinab Mohseni Afshar², Zeinab Sheidaie ${ }^{3}$, \\ Mahmoud Sadeghi-Haddad-Zavareh ${ }^{1}$, Arefeh Babazadeh ${ }^{1}$ \\ ${ }^{1}$ Istrživački centar za infektione i tropske bolesti, Zdravstveni istraživački institut, Univerzitet medicinskih nauka u \\ Babolu, Babol, Iran \\ ${ }^{2}$ Departman za infektione bolesti, Univerzitet medicinskih nauka u Kermanshahu, Kermanshah, Iran \\ ${ }^{3}$ Departman za internu medicine, Medicinski fakultet, Univerzitet medicinskih nauka u Babolu, Babol, Iran
}

\section{SAŽETAK}

Bolesnici sa Nehočkinovim limfomom kod kojih je prisutna i zahvaćenost kostiju se retko sreću. Kod ovih bolesnika su prisutne različite kliničke manifestacije u poređenju sa uobičajenim slučajevima ovog tipa kancera.

U radu je prikazan slučaj bolesnika sa Nehočkinovim limfomom, koji je prvobitno bio lečen kao osteomijelitis nepoznate etiologije. Kod ovog bolesnika pojavile su se poteškoće koje se sreću kod postavljanja dijagnoze ove bolesti.

Histopatološka dijagnoza je definitivna potvrda ove bolesti. Primarni i esencijalni tretman kod ovih bolesnika je hemoterapija.

Ključne reči: Nehočkinov limfom, osteo mijelitis, imunohistohemija 